\title{
Ernst Jünger e o demônio da técnica: modernidade e reacionarismo
}

\author{
Victor de Oliveira Pinto Coelho*
}

\section{RESUMO}

O tema do artigo é a obra de Ernst Jünger no entreguerras, em especial o ensaio $O$ trabalhador (1932). Nosso foco é apontar, na apropriação jüngeriana da técnica, seu caráter de mitologia política antiliberal. Dialogamos com o horizonte político e intelectual da época (incluindo autores como Simmel, Kracauer e Benjamin) buscando estabelecer um quadro de problematização sobre a técnica, na Alemanha, onde emerge também o chamado "Movimento Revolucionário Conservador". Apontamos, na obra de Jünger, a relação entre o "tipo" ou "figura do trabalhador" com a noção de sacrifício da individualidade em favor da mobilização total da técnica, nos termos do modernismo reacionário. Por fim, dado o fato de que em $O$ trabalhador não há referências a autores e obras, levantamos a hipótese de um diálogo subjacente com uma tradição intelectual que vem do romantismo, hipótese que conduzimos mediante uma confrontação da obra de Jünger com o tema do "acabamento assintótico" (Lacoue-Labarthe) - a impossibilidade, nos tempos modernos, de sustentar uma harmonia preestabelecida.

Palavras-chave: Ernst Jünger, técnica, modernidade, mitologia política, modernismo reacionário.

\section{ABSTRACT}

The theme of this article is Ernst Jünger's work in the interwar period, especially the essay The Worker (1932). Our focus is to point out, in the Jüngerian appropriation of technique, its character of anti-liberal political mythology. We dialogue with the political and intellectual horizon of the time (including authors such as Simmel, Kracauer and Benjamin), seeking to establish a problematization framework about the technique in Germany, where also emerges the so-called "Conservative Revolutionary Movement." We point out in Jünger's work the relationship between the "type" or "figure of the worker" and the notion of the sacrifice of individuality in favor of the total mobilization of technique, in the terms of reactionary modernism. Finally, as there are no references to authors and works in The Worker, we raise the hypothesis of an underlying dialogue with the intellectual tradition of Romanticism by

* Professor da Universidade Federal do Maranhão. São Luís - MA, Brasil.. E-mail: victor.opcoelho@ymail.com. 
confronting Jünger's work with the theme of "asymptotic completion" (Lacoue-Labarthe) - the impossibility, in modern times, of sustaining a pre-established harmony.

Keywords: Ernst Jünger; technique; modernity; political mythology; reactionary modernism.

\section{RESUMEN}

El tema del artículo es la obra de Ernst Jünger en el entreguerras, en especial el ensayo $E l$ trabajador (1932). Nuestro foco es señalar, en la apropiación jüngeriana de la técnica, su carácter de mitología política antiliberal. Dialogamos con el horizonte político e intelectual de la época (incluyendo autores como Simmel, Kracauer y Benjamin) en búsqueda de establecer un cuadro de problematización sobre la técnica, en Alemania, donde emerge también el llamado "Movimiento Revolucionario Conservador". Señalamos, en la obra de Jünger, la relación entre el "tipo" o "figura del trabajador" con la noción del sacrificio de la individualidad en favor de la movilización total de la técnica, en los términos del modernismo reaccionario. Por fin, como en El trabajador no hay referencias a autores y obras, planteamos la hipótesis de un diálogo subyacente con una tradición intelectual que viene del romantismo, hipótesis que conducimos mediante una confrontación de la obra de Jünger con el tema del "acabado asintótico" (Lacoue-Labarthe) — la imposibilidad, en los tiempos modernos, de sostener una harmonía preestablecida.

Palabras clave: Ernst Jünger; técnica; modernidad; mitología política; modernismo reaccionário.

\section{Introdução}

No filme Metropolis, de Fritz Lang, de 1927, podemos ter o vislumbre do imaginário da época, na Alemanha, a respeito das grandes metrópoles que centralizavam a expansão cada vez mais acelerada da urbanização, da industrialização e da formação da massa operária. Esta última, como a história europeia desde o século XIX já mostrara e o que foi ressaltado pela Revolução Russa de 1917, era um ator político de novo tipo, configurando-se numa força coletiva que pressionava, a partir de "baixo", os poderes político-econômicos constituídos.

Siegfried Kracauer, em seu De Caligari a Hitler, ${ }^{1}$ fez uma interessante abordagem do cinema alemão no período, tendo como centro de sua análise aspectos político-sociológicos cujo detalhamento náo vem ao caso aqui, mas que apontam para a formaçáo de uma certa classe trabalhadora oriunda não dos estratos mais populares, mas sim de uma tradicio-

\footnotetext{
${ }^{1}$ KRACAUER, Siegfried. De Caligari a Hitler: una historia psicológica del cine alemán. Tradução Héctor Grossi. Barcelona/Buenos Aires/México: Paidós, 1985.
} 
nal classe média que havia sido deslocada pela nova configuração econômica iniciada pela industrialização. Para Kracauer, esse estrato social formaria a base política do fascismo do entreguerras. Ressalte-se também o apontamento de Kracauer a respeito do ambiente político e ideológico alemão em que se realçava a figura da autoridade, presente na filmografia da época. Sobre Metropolis, então, Kracauer aponta o caráter reconciliador de classes.

Buscamos destacar mais, para os objetivos deste artigo e a título de introduçáo, o que o filme expressa em termos da preocupação da época quanto à extrema urbanização e industrialização. Em Metropolis, temos uma simbologia cristã explícita, a começar pela personagem de nome Maria. Ela surge no início do filme como uma inesperada visão para o protagonista Freder, filho do empresário Jon Fredersen, no momento em que ela trazia consigo crianças maltrapilhas, filhas dos operários da cidade. Encantado pela visão, Freder desce ao subsolo em busca de Maria e se depara com os operários que trabalham nas máquinas no subsolo da cidade, cujo proprietário é seu pai.

Mais tarde, na angelical figura de Maria será revelado um caráter subversivo. Maria discursa para os operários numa espécie de gruta - o que nos remete ao ambiente comum das minas em que se reuniram geraçóes de operários, e assim Maria seria algo como uma líder sindical clandestina. Mas Maria discursa na verdade rodeada de cruzes e sua mensagem central, que se revelará como profética, era a futura vinda de um Escolhido que pudesse ser um mediador. "O mediador entre a cabeça e as mãos deve ser o coração", sua mensagem central, será esclarecida ao final com o aperto de mãos entre Fredersen e o líder operário, Grot. Freder será o mediador e a leitura inevitável é a de que a "cabeça" é Fredersen e as "mãos" os operários, o que nos remete às concepções tradicionais sobre a ordem ou "corpo" social — daí o caráter conciliador de classes, apontado por Kracauer.

Mas voltemos o rolo do filme. Rotwang, amigo de Fredersen e a primeira encarnaçáo do "cientista louco" no cinema, toma como solução para combater Maria a construção de um clone mecânico que terá a função de levar os operários à radicalização, o que deslegitimaria a mensagem original. Devido às atividades de sabotagem postas em prática, a cidade corre risco de inundação, que começa no subsolo e ameaça de imediato os próprios operários. Podemos, neste ponto, dizer que ideologicamente a demonização recairia sobre a máquina, mas também, ambiguamente, a um potencial ludista do movimento operário, já que a sabotagem das máquinas provoca o quase desastre sobre a vida dos operários.

Decorrente desse quase desastre, Maria, a usurpadora, será queimada como bruxa, momento em que todos descobrirão se tratar de um clone robótico. Temos aí, sugestivamente, a presença do demônio da técnica, o que é reforçado com a presença do pentagrama invertido na sala em que o clone de Maria havia sido apresentado a Fredersen. Com a expressão "demônio da técnica" fazemos aqui uma remissão ao estudo de Hans Blumenberg a respeito da emergência do "homem criador": na modernidade, cada vez mais o domínio técnico é responsável pela efetiva e autêntica transformação da natureza, com a criação de mecanismos 
sem nenhuma correspondência prévia no mundo orgânico (como a hélice a motor); por outro lado, a ciência enquanto técnica, agente de uma autêntica originalidade e de domínio sobre a natureza, é acompanhada de uma pobreza de linguagem autorreflexiva. Desse descompasso, em que o "topos da imitação da natureza encobre a incompreensibilidade da originalidade humana, considerada uma violência metafísica", ${ }^{2}$ surge a expressão "o demônio da técnica".

Voltando ao filme de Lang, a aura demoníaca da técnica se faz presente também pela presença de Moloch. Conhecido também como Malcã e Baal, era cultuado por fenícios, cartagineses e cananeus, considerado símbolo do fogo purificador, por sua vez símbolo da alma, mas ficou mais conhecido por ser mencionado nos textos bíblicos como um deus ao qual os amonitas (uma etnia de Canaã) sacrificavam recém-nascidos, jogando-os numa fogueira cuja abertura, segundo as representaçóes do deus, localizava-se no dorso ou base de sua estátua. No filme, na passagem citada em que Freder desce ao subsolo, Moloch surge como transfiguração da máquina central após um acidente que expôs a curta fronteira entre a vida e a morte dos operários em seu trabalho nas máquinas.

Moloch se faz presente também no ensaio de Ernst Jünger $O$ trabalhador. Dominio e figura (Der Arbeiter. Herrschaft und Gestalt), de 1932. Nele, Moloch tem um caráter de alegoria para o sacrifício da individualidade em prol da mobilização total da técnica. Embora não abandone a ideia de corpo social — já que há uma hierarquia interna na figura do trabalhador, que pressupóe o Estado como seu tipo (Typus) mais acabado —, a conciliação proposta é agora a do homem com a máquina. Para Jünger,

Tudo aquilo que sentimos no nosso tempo como admirável, e que ainda nos fará aparecer, nas lendas dos séculos mais longínquos, como uma estirpe de feiticeiros poderosos, pertence a esta substância, pertence à figura do trabalhador. É ela que opera na nossa paisagem, a qual só não sentimos como infinitamente estranha porque nascemos nela; o seu sangue é o combustível que impulsiona as rodas e fumega nos seus eixos.

$\mathrm{Na}$ consideração deste movimento, apesar de tudo monótono, que lembra um campo cheio de mosteiros tibetanos, na consideração da ordem rigorosa destes sacrifícios, que se assemelha aos esboços geométricos das pirâmides, sacrifícios tais como ainda não exigiu nenhuma Inquisição nem nenhum Moloch, e cujo número se multiplica a cada passo com uma segurança mortal — como poderia aqui um olhar que realmente quer ver furtar-se à visão de que atrás do véu da causa e efeito, que se agita sob os combates do dia, operam o destino e a veneraçấo?3

Neste artigo, pretendemos destacar alguns elementos centrais da obra de Jünger no en-

\footnotetext{
${ }^{2}$ BLUMENBERG, Hans. "Imitação da natureza": contribuição à pré-história da ideia do homem criador. In: COSTA LIMA, Luiz (Org.). Mímesis e a reflexão contemporânea. Tradução Luiz Costa Lima; revisão técnica Carlinda Nuñez. Rio de Janeiro: EdUerj, 2010, p. 95.

${ }^{3}$ JÜNGER, Ernst. O trabalhador. Domínio e figura. Introdução, tradução e notas Alexandre Franco de Sá; prefácio Nuno Rogeiro. Lisboa: Hugin, 2000, \$12, p. 94. (Para consulta ao original: Der Arbeiter. Herrschaft und Gestalt. $3^{\text {te }}$ Auflage. Stuttgart: Klett-Cotta, 2007).
} 
treguerras europeu, especialmente a obra $O$ trabalhador, para iluminar seu caráter ultrarreacionário. No tópico a seguir, iremos contextualizá-la no horizonte intelectual da época a respeito da emergência do problema da técnica.

\section{Ernst Jünger e o problema da técnica na Alemanha do entreguerras}

Nascido em 1895, Ernst Jünger lutou como soldado na Primeira Guerra Mundial, tendo se alistado como voluntário e recebido várias condecoraçóes, tais como a Cruz de Ferro, que lhes deram a aura de herói de guerra - algo que, por sua vez, lhe daria um status especial no contexto político do entreguerras. Ao longo dos anos da República de Weimar, Jünger escreveu vários livros cujos temas giravam em torno do tema da guerra e do heroísmo, tendo destaque o já mencionado ensaio $O$ trabalhador e, antes dele, o diário de guerra In Stahlgewittern (Tempestades de Aço, 1920), ${ }^{4}$ a mistura de ensaio e diário de guerra Der Kampf als inneres Erlebnis (A guerra como experiência interior, 1922), ${ }^{5}$ entre outros. Escrevia também ensaios políticos nas publicaçóes Die Standarte, Arminius e Vormarsch, voltadas especialmente para ex-combatentes, que ajudava a organizar. Embora nunca tenha se filado ao Partido Nazista, sua obra contribuiu política e intelectualmente para a ascensão do fascismo alemão. "Mais que qualquer outro dentre os revolucionários conservadores de proa", destacou Jeffrey Herf, "Jünger recorreu à Fronterlebnis (experiência do front) da Primeira Guerra Mundial a fim de conciliar reação política com tecnologia moderna" sendo que ela, a Fronterlebnis, "era sua utopia concreta, para usar o termo de Ernst Bloch; utopia que prefigurava uma comunidade não contaminada pelas relaçóes de troca capitalista". ${ }^{6}$

Naquela época, como pontuou Herf em seu $O$ modernismo reacionário, os alemães buscavam o desafio de unir a técnica moderna ao princípio da Kultur, rejeitando-se a razão iluminista em prol de um projeto político tradicionalista e autoritário. Nesse contexto, Jünger foi "um esteta ideal-típico da direita e, a exemplo de outros membros da vanguarda europeia, sentia-se atraído pela tecnologia porque acreditava que esta pudesse ajudar a estetizar a política e assim resolver uma crise de decadência e declínio cultural", diz o autor, e devemos ter em conta também a obra O declínio (ou decadência) do Ocidente (1918) de Oswald Spengler, que teve grande repercussão à época.

Segundo Hermínio Martins, ${ }^{7}$ a literatura sociológica a respeito da questáo da técnica,

\footnotetext{
${ }^{4}$ JÜNGER, Ernst. Tempestades de aço. Tradução e notas Marcelo Backes. 1. ed. digital. São Paulo: Cosac Naify, 2013.

${ }^{5}$ JÜNGER, Ernst. A guerra como experiência interior. Tradução Armando Costa e Silva; revisão a partir do alemão Roberto de Moraes. Lisboa: Ulisseia, 2005.

${ }^{6}$ HERF, Jeffrey. O modernismo reacionário: tecnologia, cultura e política na República de Weimar e no Terceiro Reich. Tradução Claudio Frederico da S. Ramos. São Paulo: Ensaio; Campinas: Unicamp, 1993, p. 85.

${ }^{7}$ MARTINS, Hermínio. Tecnologia, modernidade e política. Lua Nova, n. 40, 1997, p. 282-320.
} 
entre os séculos XIX e XX, girou em torno de noçôes tais como "domínio", "controle” ou "conquista" da natureza e pode ser dividida em duas tradiçôes ideais-típicas: a "Prometeica" e a "Fáustica" - a primeira acentuada após a Revolução Francesa e a segunda culminando com as reflexóes de Martin Heidegger. Sem desconsiderar suas variantes internas,

a tradição Prometeica liga o domínio técnico da natureza a fins humanos e sobretudo ao bem humano, à emancipação da espécie inteira e, em particular, das "classes mais numerosas e pobres" (na formulação Saint-Simoniana). A tradição Fáustica esforça-se por desmascarar os argumentos Prometeicos, quer subscrevendo, quer procurando ultrapassar (sem solução clara e inequívoca) o niilismo tecnológico, condição pela qual a técnica não serve qualquer objetivo humano para além da sua própria expressão. ${ }^{8}$

O que importa aqui é apontar que, no caso da visão fáustica da técnica e da ciência, sua primeira formulação geral, nos termos de uma abordagem da história mundial, foi aquela elaborada por Spengler em sua obra mencionada, "para coincidir (intencionalmente) com o súbito e completamente inesperado colapso militar e industrial da Alemanha". Mas sua influência na Alemanha se deu menos em sua pretensão de totalizar a história mundial e mais nas leituras que o viam como uma síntese de diagnóstico e prognóstico de uma crise para o Ocidente e o mundo. Segundo Martins, de acordo com essa leitura, a técnica não derivaria "primariamente de uma racionalidade cognitiva anterior (a 'razão soberana'), mas pode antes ser vista como manifestadora dos valores básicos (a 'vontade soberana') de uma cultura; esta pode ser chamada uma teoria expressivista da técnica"10 — expressão de uma "vontade de vontade", e o autor recorda o peso que tinha, na Alemanha, a noção de Lebensphilosophie ("filosofia da vida"). A isso se ligaria a legitimação da técnica e da ciência-como-tecnologia "pelos engenheiros-filósofos na Alemanha de Weimar, os quais procuraram enfatizar as facetas culturais (não instrumentais, calculativas, transferíveis, universalistas) da técnica". ${ }^{11}$

Assim, no contexto da crise da Alemanha após a Grande Guerra de 1914-1918, as análises do tipo fáustico são favorecidas, contrapondo à fé na racionalidade da história (nas suas supostas leis ou dialética) uma visão "destinarista" da técnica e da história, recusando "qualquer visão libertária da neutralidade ou do caráter puramente instrumental da técnica". ${ }^{12}$ Bem como hostilizavam os valores liberais, democráticos e universalistas ocidentais.

\footnotetext{
${ }^{8}$ Ibidem, p. 290.

${ }^{9}$ Ibidem, p. 306.

${ }^{10}$ Ibidem, p. 312.

${ }^{11}$ Ibidem, 1997, p. 312. Cf., a esse respeito, HERF, Jeffrey. O modernismo reacionário, op. cit.

${ }^{12}$ MARTINS, Hermínio. Tecnologia, modernidade e política, op. cit., p. 314.
} 
A rejeição radical do princípio liberal da liberdade individual como fundamento do político (ou do Direito) é o que aproximava o pensamento de Jünger com os de Carl Schmitt e Martin Heidegger, ${ }^{13}$ no contexto do que ficou conhecido como Movimento Revolucionário Conservador alemão (ou Revolução Conservadora). Para a formulação heideggeriana sobre o niilismo, no final da década de 1930, teria importância a obra de Jünger: em seu Nietzsche há a menção ao tipo do trabalhador como consumação da metafísica do sujeito:

O tipo unifica em si de uma maneira modificada o elemento único, que foi anteriormente requisitado pelo indivíduo, e a similaridade e a universalidade, que são exigidas pela comunidade. Mas a unicidade do "tipo" consiste em uma clara prevalência da mesma cunhagem que, contudo, não tolera nenhum igualitarismo desertificante, mas carece de uma hierarquia peculiar. Na ideia nietzschiana do além-do-homem não se prelineia um "tipo" particular de homem, mas antes, pela primeira vez, o homem sob a figura essencial do "tipo". Precursores são o soldado prussiano e a ordem dos jesuítas, que são caracterizados por uma mistura peculiar de sua essência, uma mistura na qual o conteúdo interno de seu primeiro surgimento histórico pode ser quase completamente ignorado. ${ }^{14}$

A ordem jesuíta e o exército prussiano, além dos cavaleiros teutônicos, haviam sido elencados em $O$ trabalhador como modelos de uma vida espartana que se faria presente agora, mobilizando o mundo, na paisagem das oficinas ${ }^{15}$ - e por isso seriam então como que prefiguraçóes da figura ou tipo do trabalhador. Mas já se tratava de uma apropriação da obra nietzschiana $A$ vontade de poder: "A obra de arte", instância escolhida por

${ }^{13}$ Cf. COELHO, Victor de O. P. Entre o niilismo e a legitimidade do espaço simbólico. Diálogo com Schmitt, Heidegger e Blumenberg. Horizonte: Revista de Estudos de Teologia e Ciências da Religião, v. 12, p. 183-210, 2014. Ressalte-se que Carl Schmitt, figura de proa daquilo que se convencionou chamar de Movimento Revolucionário Conservador alemão, já desde a segunda metade da década de 1910 debruçava-se sobre o problema da técnica, tendo formulado um conceito de secularização que dizia respeito justamente ao domínio da técnica no mundo moderno, os "tempos de imediatez": a absorção da vida humana nos processos fáticos e a negação das dualidades, em especial aquela entre mundo fático e esfera transcendente. Essa dissolução da dualidade era o cerne da crítica de Schmitt ao legado liberal, que havia deslocado o sentido ou valor transcendente em favor da imanência - liberdade - do sujeito individual. Cf. COELHO, Victor de O. P. Carl Schmitt. Ernst Jünger e o problema da totalidade na era da técnica. In: BUENO, Roberto (Org.). Carl Schmitt hoje: política, direito e teologia. São Paulo: Max Limonad, 2015, p. 579-601.

${ }^{14}$ HEIDEGGER, Martin. O niilismo europeu. In: HEIDEGGER, Martin. Nietzsche II. Tradução Marco Antônio Casanova. Rio de Janeiro: Forense Universitária, 2007, p. 107-108. "Heidegger havia discernido em relação crítica com o livro de Ernst Jünger, Der Arbeiter — o sentido histórico-universal do movimento nacional-socialista como consistindo no seguinte: ele almejava uma harmonia entre o homem e a técnica. Uma nova humanidade, uma espécie de super-homem (Uebermensch) que correspondesse às modernas possibilidades técnicas e as reconciliasse com o enraizamento no solo pátrio (das Bodenständige). Em torno de 1933, Heidegger considerava o nazismo uma saída para o principal problema moderno, a saber: a técnica e suas consequências sobrepujam o homem.” MAURER, Reinhart. O que existe de propriamente escandaloso na filosofia da técnica de Heidegger. Natureza Humana, v. 2, n. 2, p. 403-427, 2000, p. 404-405.

${ }^{15}$ JÜNGER, Ernst. O trabalhador. Domínio e figura. op. cit., \$60, p. 196. 
Nietzsche como lócus privilegiado para a expressão da vontade, "ali onde ela aparece sem artista, por exemplo: como corpo, como organização (corpo de oficiais prussiano, ordem jesuítica) (...)". ${ }^{16}$

Essa exaltação vitalista da técnica tem um caráter declaradamente bélico, ligando-se à reivindicação da já mencionada experiência no front de batalha. A novidade de Jünger, como apontou Herf, será ligar esse vitalismo guerreiro à própria técnica ao mesmo tempo que dá à guerra um caráter vital (orgânico).

Nas obras de Jünger, exatamente naqueles pontos em que a descrição do vigor do espetáculo ameaça amortecer sua celebração da vontade, ele encontra um sujeito coletivo para restaurar tanto a cultura quanto a política revolucionária conservadora: "Hoje escrevemos poesia a partir do aço e da luta pelo poder em batalhas onde os acontecimentos se engrenam com a precisão das máquinas. Nessas batalhas na terra, na água e no ar, repousa uma beleza que somos capazes de antegozar. Lá a impetuosa vontade do sangue se refreia e depois se expressa pelo domínio das maravilhas técnicas do poder". ${ }^{17}$

Nossa hipótese é que, em especial em seu longo ensaio $O$ trabalhador, Jünger sistematiza essa Lebensphilosophie bélica numa exaltação do mundo industrial moderno como a possibilidade de uma nova totalidade: com Jünger e sua figura (Gestalt) ou tipo do trabalhador, temos uma "solução" no ambiente político-intelectual da modernização conservadora alemá: a subjetividade individual deve se sacrificar em prol da mobilização total da técnica, no espaço industrial e na guerra. Como já foi apontado antes, ${ }^{18}$ a racionalidade iluminista é trocada pela "linguagem sem palavras" da técnica e esta, por sua vez, deve ser encarada em sua dimensão cultual. Enfim, a totalidade ideal, enquanto "terceira instância" (Humboldt) entre os cidadãos e a contingência, daria lugar novamente a uma totalidade ontológica: a totalidade do trabalho; e a natureza idílica, índice da totalidade perdida e presente nos movimentos neorromânticos reacionários, dá lugar à natureza planificada do trabalho.

$\mathrm{Na}$ mitologia política que pretendemos destacar a partir da obra jüngeriana, é preciso iluminar aquele que talvez seja o ponto mais obscuro da obra de Jünger: o elogio ao sacrifício.

\footnotetext{
${ }^{16}$ NIETZSCHE, Friedrich. A vontade de poder. Tradução e notas Marcos Sinésio Pereira Fernandes, Francisco José Dias de Moraes, apresentação Gilvan Fogel. Rio de Janeiro: Contraponto, 2008, \$796, p. 397.

${ }^{17}$ HERF, Jeffrey. O modernismo reacionário, op. cit., p. 92-93. A passagem destacada por Herf é de A guerra como experiência interior.

${ }^{18}$ COELHO, Victor de O. P. A totalidade enquanto problema histórico e categoria teórica: uma abordagem a partir das obras de Humboldt, Simmel e Ernst Jünger. Revista de Teoria da História, ano 4, n. 8, p. 78-105, dez./2012.
} 
O Moloch jüngeriano: o sacrifício da subjetividade no altar da natureza planificada do trabalho

Como observou Anton Kaes, ${ }^{19}$ não apenas na obra de Jünger, mas também no horizonte intelectual (o termo é nosso) que marcava a Alemanha nos anos que se seguiram à Primeira Guerra Mundial, havia uma percepção de que o processo de militarização e mobilização posto em marcha pela guerra não havia cessado após seu fim. É nesse sentido que o autor traça um paralelo entre outro filme de Lang, $M$ - Eine Stadt sucht einen Mörder ( $M-O$ vampiro de Düsseldorf), de 1931, e o filme Westfront 1918, de 1930, dirigido por Georg Wilhelm Pabst e baseado no romance Vier von der Infanterie (Quatro de Infantaria. Frente Ocidental, 1918), de Ernst Johannsen, publicado no ano anterior. Como coloca o autor, embora o filme de Lang não tenha como tema a guerra, que é o que constitui o enredo do filme de Pabst, eles revelam uma similaridade na medida em que o primeiro apresenta Berlin como uma cidade em estado de total mobilização, preparada para enfrentar o inimigo, que toma a forma de um invisível assassino em série. Fazendo referência também à obra de Brecht Mann ist Mann ("O homem é o homem"), da mesma época (1926), Kaes aponta o sentido de objetivação do espaço urbano com a desintegraçáo do indivíduo, num momento em que parece se expandir o anonimato e a desintegração do espaço social da cidade.

Como aponta o autor, as obras de Jünger das décadas de 1920 e 1930 antecipam em várias décadas a reflexão de Paul Virilio sobre a cidade superexposta, mas em sinal político inverso, devido ao elogio do domínio de uma visão objetiva e fria, materializada na fotografia. Teríamos aqui uma ambivalência com, de um lado, um olhar perscrutador e vigilante (Kaes faz também referência a Vigiar e punir, de Foucault) e, de outro, uma maneira de lidar com a ansiedade gerada pelos choques da modernidade, sejam eles provocados pela própria técnica, seja pela mencionada desintegração no espaço urbano da metrópole.

Nos ensaios tais como "Guerra e fotografia" (Krieg und Lichtbild, 1930), ${ }^{20}$ "Sobre o perigo" (Über die Gefahr, 1931) ${ }^{21}$ e "Sobre a dor" (Über den Schmerz, 1934), ${ }^{22}$ bem como na coletânea $O$ coração aventuroso (Das abenteuerliche Herz, 1929), ${ }^{23}$ essa ideia de uma Nova Objetividade, que implica um "olhar frio e objetivo", emerge como capacidade de o ser

${ }^{19}$ KAES, Anton. The Cold Gaze: Notes on Mobilization and Modernity. New German Critique, n. 59, Special Issue on Ernst Junger, p. 105-117, Spring/Summer, 1993. Disponível em: <http://www.jstor.org/ stable/488225>. Acesso em: 2 maio 2011.

${ }^{20}$ Cf. JÜNGER, Ernst. War and Photography. Tradução Anthony Nassar. New German Critique, n. 59, Special Issue on Ernst Junger, p. 24-26, Spring/Summer, 1993. Disponível em: <http://www.jstor.org/stable/488220>. Acesso em: 24 maio 2011.

${ }^{21}$ Cf. JÜNGER, Ernst. On Danger. New German Critique, n. 59, Special Issue on Ernst Junger, p. 27-32, Spring/Summer, 1993. Disponível em: <http://www.jstor.org/stable/488221>. Acesso em: 24 maio 2011.

${ }^{22}$ Cf. JÜNGER, Ernst. Sobre el dolor. In: JÜNGER, Ernst. Sobre el dolor, seguido de La mobilización total y Fuego y movimiento. Tradução do alemão Andrés Sánchez Pascual. 2. ed. Barcelona: Tusquets, 2003, p. 34. ${ }^{23}$ JÜNGER, Ernst. O coração aventuroso. Tradução Ana Cristina Pontes. Lisboa: Cotovia, 1991. 
humano tratar o corpo como um objeto e lançá-lo, à distância, no combate e no sacrifício. A isso se liga uma crítica ao desejo burguês por segurança. Tais tematizaçôes serão sistematizadas no ensaio $O$ trabalhador. $O$ perigo, para Jünger, "não apenas quer ter parte em qualquer ordem, mas é também a mãe daquela segurança suprema da qual o burguês nunca poder tornar-se participante". ${ }^{24}$ Seguindo o ponto de vista do pensamento jüngeriano, como veremos, há apenas um paradoxo aparente entre o elogio do perigo e a reivindicação de uma "segurança suprema".

Como revela a obra de Jünger, há o sentido de uma certa fusão ou perda de fronteiras pelo próprio adensamento dos espaços na vida moderna e entre os diversos tipos de atividades, que passam a ter o que Jünger definiu como a máscara da uniformidade. Na seção "A rendição do indivíduo burguês pelo tipo do trabalhador", Jünger usa a metáfora da "crisálida em que a imago consome a lagarta", assim como a da "massa rochosa que se perdeu durante a formação de uma estátua de pedra”, para afirmar que chegamos "a uma parte em que a história do desenvolvimento se torna impotente, se não for empreendida com sinais invertidos; isto é, empreendida desde uma perspectiva a partir da qual a figura, enquanto ser não submetido ao tempo, determina o desenvolvimento da vida em devir". Mas aqui, diz Jünger, "descobrimos uma mudança que a cada passo ganha em inequivocidade". 25

Assim, temos uma mudança que está mais conforme a processos naturais, ou mesmo de processos metafísicos (a figura "enquanto ser não submetido ao tempo") e que poderíamos, a nosso ver, contrastar com o sentido da diacronia histórica tal como vivida desde o século XIX, com suas contradiçóes. Dada a emergência do tipo, diz Jünger, "a primeira impressão que [ela] suscita é a de um certo vazio e uniformidade", uniformidade "que torna muito difícil a diferenciaçáo individual dentro de uma substância de raças estranhas, animais ou humanas". ${ }^{26} \mathrm{O}$ primeiro exemplo disso é a máscara:

Aquilo que à partida se mostra, de um modo puramente fisionômico, é a rigidez do rosto, como uma máscara, que é tanto adquirida como acentuada e aumentada através de meios exteriores, como a ausência de barba, o penteado e um chapéu justo. Que neste caráter de máscara, que desperta nos homens uma impressão metálica, nas mulheres uma impressão cosmética, venha à luz um processo muito incisivo, pode-se concluir já de ele mesmo conseguir polir as formas através das quais o caráter dos sexos se torna fisionomicamente visível. Não é por acaso, diga-se de passagem, o papel que desde há pouco a máscara recomeça a desempenhar na vida quotidiana. Ela aparece de modos variados em locais onde irrompe o caráter especializado do trabalho, seja como máscara de rosto para o desporto e para altas velocidades, tal como a possui

\footnotetext{
${ }^{24}$ JÜNGER, Ernst. O trabalhador. Domínio e figura, op. cit., $\$ 13$, p. 77.

${ }^{25}$ Ibidem, $\$ 36$, p. 130-131.

${ }^{26}$ Ibidem, $\$ 36$, p. 131.
} 
qualquer automobilista, seja como máscara de proteção no trabalho num espaço ameaçado por radiaçōes, explosōes ou difusão de narcóticos. ${ }^{27}$

Esse caráter de máscara pode ser relacionado também, segundo Jünger, ${ }^{28}$ à difusão do "exercício do corpo, um exercício completamente determinado e planeado, o training", assim como na "mudança que se realiza em relação ao vestuário", em que o velho traje burguês, que pode ser tomado "como a reminiscência informal das velhas fardas dos estados, começa a tornar-se de algum modo absurdo em qualquer dos seus pormenores". O "vestuário burguês tornou-se civil", e no geral essa uniformização se observa no próprio uniforme, tal qual o uniforme militar, "mudança cujo primeiro sinal se anuncia em as cores variadas da farda se reduzirem aos matizes monótonos da paisagem de combate". E enquanto "o vestuário burguês se desenvolveu com base nas velhas fardas dos estados, a farda do trabalho ou o uniforme de trabalho indicam um caráter em si autônomo e completamente diferente", pertencem "às marcas exteriores de uma revoluçáo sans phrase", sendo sua tarefa não realçar a individualidade, "mas a de acentuar o tipo". Agora até mesmo o modo de vestir dos deputados e ministros de Estado começa a uniformizar-se, no sentido da dissolução dos estamentos e também da rígida separação entre público e privado: "Mostra-se à massa como se come e bebe, e o que se faz no desporto ou nas casas de campo; surgem aquelas imagens em que o ministro aparece em fato de banho, o monarca constitucional em traje de rua e num ambiente ligeiro de conversa"; e, por sua vez, "a decadência no modo como as massas se vestem corresponde à decadência da fisionomia individual".

Esse caráter de uniformidade, que acompanha a dissolução da individualidade, havia sido apontado por Kracauer em seu ensaio "O ornamento da massa", em 1927. Para ele, no "domínio da cultura do corpo, que também invadiu as revistas ilustradas, ocorreu silenciosamente uma mudança de gosto", e afirma que tal processo teria começado com a companhia de dança das Tillergirls.

Esse produto das fábricas americanas de distração já não é mais constituído por garotas individuais, mas complexos indissolúveis de garotas, cujos movimentos são demonstraçôes matemáticas. Enquanto elas se condensam em figuras nos teatros de revistas, espetáculos da mesma precisão geométrica acontecem no mesmo estádio sempre lotado na Austrália e na Índia, para não falar na América. A menor das localidades, na qual esse espetáculo ainda não foi divulgado, será informada por meio do cinejornal da semana. Basta um olhar na tela para entender que os ornamentos consistem em milhares de corpos, assexuados, em roupas de

\footnotetext{
${ }^{27}$ Idem.

${ }^{28}$ Ibidem, $\$ 36$, p. 131-134, para todas as citaçôes deste parágrafo. No sentido do exposto no parágrafo, cf. também, por exemplo, ibidem $\$ 31$, p. 118: "[Para] onde quer que o olhar se dirija, recai sobre um trabalho que é realizado neste sentido anônimo.”
} 
banho. A regularidade de seus desenhos é aplaudida pela massa, disposta ordenadamente nas tribunas. $^{29}$

Antes de qualquer coisa, é interessante notar o nexo entre aquilo que Kracauer e Jünger expóem a respeito da uniformizaçáo que acompanha a sociedade de massa. Para o segundo, o caráter de máscara do tipo corresponde a uma "caractereologia matemática e 'científica', com uma investigação da raça, que se estende até à medição dos glóbulos sanguíneos", um "desejo espacial de uniformidade" a que corresponde, "no temporal, a preferência pelo ritmo, em particular também pela repetição - ela conduz aos esforços para ver inteiras imagens do mundo como repetições, segundo uma lei rítmica, de um e do mesmo processo fundamental". ${ }^{30}$

No entanto, enquanto Kracauer relacionava essa estética de massa com os mecanismos do próprio capitalismo e desejava um processo de libertação pela razão (em meio ao processo de desencantamento posto em marcha), a obra de Jünger representa justamente aquilo que Kracauer via como a prisão de uma ratio mecanizada que submete a razão livre. ${ }^{31}$ Contudo, e como observou Andreas Huyssen, ${ }^{32}$ Kracauer se equivocava ao ver em $O$ trabalhador um caminho para fora da política. Concordamos com Huyssen no sentido de que, embora seja preciso evitar uma polarização entre arte moderna e fascismo (bem como evitar tomar, como uma mesma coisa, modernismo e autoritarismo eurocêntrico, à maneira pós-modernista), o fato de a obra de Jünger representar uma contraposiçâo à reflexão crítica tão cara às vanguardas de esquerda não faz de sua obra anti ou apolítica. Muito pelo contrário, trata-se justamente da expressão de um pensamento simultaneamente revolucionário e conservador.

$\mathrm{O}$ que Jünger denomina como mobilização tota ${ }^{33}$ ultrapassa o espaço restrito das oficinas, diz tanto sobre o trabalho nas fábricas como sobre o soldado no campo de batalha, apresentando "o caráter do cálculo construtivo". ${ }^{34}$ Destacando, pois, uma crescente capacidade de mobilização da técnica no sentido da transformação e modificação do espaço, em que as

\footnotetext{
${ }^{29}$ KRACAUER, Siegfried. O ornamento da massa. In: KRACAUER, Siegfried. O ornamento da massa: ensaios. Tradução Carlos Eduardo Jordão Machado e Marlene Holzhausen. São Paulo: Cosac Naify, 2009, p. 92.

${ }^{30}$ JÜNGER, Ernst. O trabalhador. Domínio e figura, op. cit., \$41, p. 147.

${ }^{31}$ Para uma análise da obra de Kracauer, cf. HANSEN, Miriam. (Prefácio) Perspectivas descentradas. In: KRACAUER, Siegfried. O ornamento da massa, op. cit. e LEVIN, Thomas Y. Introduction. In: KRACAUER, Siegfried. The mass ornament: Weimar Essays. Tradução, edição e introdução Thomas Y. Levin. Cambridge/Massachusetts/London/England: Harvard University Press, 1995, p. 1-30.

${ }^{32}$ HUYSSEN, Andreas. Fortifying the Heart: Totally Ernst Jünger's Armored Texts. New German Critique, n. 59, Special Issue on Ernst Junger, p. 3-23, Spring/Summer, 1993. Disponível em: <http://www.jstor.org/ stable/488219>. Acesso em: 2 maio 2011.

${ }^{33}$ Cf. JÜNGER, Ernst. A mobilização total. Tradução e notas Vicente Sampaio. Natureza Humana, v. 4, n. 1, p. 189-216, jan./jun. 2002. Disponível em: <http://pepsic.bvsalud.org/scielo.php?script=sci_arttext\&pi $\mathrm{d}=$ S1517-24302002000100006>.

${ }^{34}$ JÜNGER, Ernst. O trabalhador. Domínio e figura, op. cit., \$77, p. 257.
} 
estruturas "crescem como por golpes mágicos", Jünger observa que, enquanto "nas primeiras medidas em que se pode falar de um plano de trabalho neste sentido particular, como no programa alemáo de fornecimento de armas e muniçôes de 1916, a iniciativa privada ainda desempenha um grande papel”, por outro lado,

no primeiro plano quinquenal russo, quase já não há sequer um trabalhador que possa determinar a escolha ou a rescisão do seu local de trabalho por medida própria. A execução incompleta e a dissoluçáo da lei do dever de serviço de trabalho constituíram aliás um dos fundamentos da derrota alemâ. ${ }^{35}$

Assim, o domínio da figura do trabalhador se dá "horizontalmente" pela junção (ou sacrifício) do homem com a máquina e "verticalmente" pelo domínio do Estado enquanto grau máximo da figura e instância de planejamento, com Jünger inspirando-se no plano quinquenal "russo" (ou seja, soviético). O plano [Plan], "tal como surge dentro da democracia de trabalho, ou seja, dentro de um estado de passagem, mostra-se através das características do acabamento, da flexibilidade e do armamento. Estas características comprovam", diz Jünger, "do mesmo modo que a palavra 'plano' em si, que aqui não se pode tratar de medidas definitivas". No entanto, a paisagem planificada diferencia-se "da pura paisagem de oficinas por possuir objetivos solidamente demarcados". ${ }^{36}$ Nessa totalidade do trabalho, o "tráfego desenvolveu-se no sentido de uma espécie de Moloch, que, ano sim, ano não, devora uma soma de vítimas que só se podem comparar às da guerra. Estas vítimas caem numa zona moralmente neutra; o modo em que são percebidos é de natureza estatística". ${ }^{37}$

Nesse ponto em que o desprezo pela individualidade é a expressão do caráter totalitário de tal pensamento, evidencia-se também o fio nietzschiano presente em Jünger, pois essa neutralidade moral, intrínseca à expansão estatística da técnica, revela uma vontade de poder: o "sentido anônimo", ligado ao "pano de fundo" do progresso, corresponde a uma "embriaguez do conhecimento que é mais do que de origem lógica, e há um orgulho nas proezas técnicas, no começo do domínio ilimitado sobre o espaço, que possui uma suspeita da mais misteriosa vontade de poder". ${ }^{38}$ Assim, à sua maneira, Jünger tira o caráter supostamente neutro da técnica para dar-lhe um caráter de culto.

por vezes, quando de repente a tempestade dos martelos e das rodas que nos rodeia se silencia, a tranquilidade que se esconde atrás da desmedida do movimento parece contrariar-nos quase corporalmente, e é bom o costume do nosso tempo, para honrar os mortos ou para gravar na consciência um instante de significado histórico, declara suspenso o trabalho por um intervalo

\footnotetext{
${ }^{35}$ Ibidem, $\$ 77$, p. 258.

${ }^{36}$ Ibidem, $\$ 75$, p. 249.

${ }^{37}$ Ibidem, $\$ 30$, p. 116 .

${ }^{38}$ Ibidem, $\$ 12$, p. 74.
} 
de minutos, como por um comando supremo. Pois este movimento é uma alegoria da força mais íntima, no sentido em que o significado misterioso de um animal se manifesta o mais claramente possível no seu movimento. Mas o espanto sobre a sua suspensão é, no fundo, o espanto sobre o ouvido julgar perceber, por um instante, as fontes mais profundas que alimentam o curso temporal do movimento, e isso eleva este ato a uma dignidade de culto. ${ }^{39}$

Em Tempestades de aço, Jünger apresenta a guerra com um caráter sublime que de certa forma, através da explosão sem medida do poderio técnico e da descrição de um tipo de soldado parecido com "o habitante de um mundo estranho, dotado de maior dureza", poderia ser lida como uma "preparação" para a formulação da totalidade da técnica em $O$ trabalhador. ${ }^{40}$ Tal figura do soldado foi assim descrita por Jünger:

Diante de nós, rolava e trovejava um fogo de artilharia de uma força jamais imaginada; a oeste, milhares de claróes palpitantes faziam do horizonte um mar de chamas.

(...) Um mensageiro de um regimento de Württemberg veio ter comigo. (...) Foi o primeiro soldado alemão que vi usando capacete de aço e me pareceu, de imediato, um habitante de um mundo estranho e mais duro. (...) perguntei-lhe, ansioso, pela situação na trincheira, e ouvi uma narrativa monótona sobre dias agachados em crateras abertas pelas granadas, sem caminhos de ligação nem de aproximação, sobre ataques intermináveis, sobre campos de cadáveres e uma sede louca, sobre feridos convalescendo e sobre outras coisas mais. $\mathrm{O}$ rosto imóvel, emoldurado pela borda do capacete de aço, e a voz monocórdia, acompanhada pelo barulho do front, nos causavam uma impressão fantasmagórica. Poucos dias carimbaram aquele mensageiro que deveria nos acompanhar ao reino das chamas, marcando-o com um selo que parecia diferenciá-lo de um modo indizível.

(...) Nada restava naquela voz a não ser uma grande indiferença; ela havia sido calcinada pelo fogo. Com homens assim se pode lutar. ${ }^{41}$

\footnotetext{
${ }^{39}$ Ibidem, $\$ 12$, p. 74 . “(...) é precisamente atrás da aparência desta neutralidade que se esconde a lógica misteriosa e tentadora com que a técnica entende mostrar-se aos homens”. Ibidem, $\$ 47$, p. 162. Também Oswald Spengler, em O homem e a técnica, de 1931, apontou como problema o assalto da técnica pelo economicismo e pelo materialismo. Para ele, a técnica teria mais a ver com um impulso básico do homem enquanto disposição de vida e de domínio da natureza e aqueles que "não sentiam em si essa Vontade de Domínio sobre a Natureza atribuíram, necessariamente, a este projeto uma virtualidade diabólica. De fato, sempre houve quem considerasse as máquinas como invenção do Demônio", diz Spengler, lembrando que a "partir de Roger Bacon, é longa a série de sábios que vão sendo apodados de mágicos e heréticos". Cf. SPENGLER, Oswald. O homem e a técnica. Tradução João Botelho; prefácio Luís Furtado. 2. ed. Lisboa: Guimarães Editores, 1993, p. 102103. No entanto, a narrativa trans-histórica de Spengler acaba por terminar com um sentido trágico-fatalista de inevitável derrota frente às forças da Natureza.

${ }^{40}$ É a hipótese colocada em COELHO, Victor de O. P. Ernst Jünger: o sublime da guerra e o tempo como mudança de plano. Dimensóes, v. 30, p. 173-212, 2013.

${ }^{41}$ JÜNGER, Ernst. Tempestades de aço, op. cit. (cap. "Guillemont”, \$\$ 4-7).
} 
Essa descrição de Jünger de um novo tipo de soldado, duro, corresponde à metáfora dos "textos blindados" (armored texts) com que Huyssen classifica os ensaios de Jünger, contrapondo-os à abertura crítica proporcionada pelo modernismo. Para o autor, apesar da heterogeneidade, se entendermos o modernismo na literatura como problematização da estabilidade e transparência da representação, da linguagem ou da subjetividade, então Jünger não seria modernista, já que seus textos evitam tal confrontação. ${ }^{42}$ À parte uma discussão e conceitualização sobre o modernismo, que não é nosso objetivo, acreditamos que essa categorização dos textos de Jünger como "textos blindados" é bem pertinente.

Se, por um lado, Jünger se coloca crítico do desejo de segurança burguês e da incapacidade burguesa de estabelecer um autêntico comando em meio à mobilização total, e ainda que não reivindicasse para si a identidade fascista, sua defesa de uma nova totalidade acaba se configurando num projeto de reestabelecimento de uma Ordem, tão absoluta que apresenta o caráter de uma metafísica:

Assim, não há nenhum homem mecânico; há máquinas e homens - mas há certamente uma uniáo profunda entre a simultaneidade dos novos meios e de uma nova humanidade. Para captar esta uniáo, tem de se esforçar por ver através das máscaras do tempo, feitas de aço e humanas, para adivinhar a figura, a metafísica, que as movimenta.

Assim, e só assim, a partir do espaço de um supremo carácter unitário, se pode tomar a relação existente entre uma espécie humana particular e os meios peculiares que estão à sua disposiçáo. Por todo o lado onde aqui é sentida uma dissonância, o erro deve ser procurado no local do observador, mas não no ser. ${ }^{43}$

Segundo Jünger, passava a vir "à luz uma tendência que procura captar de acordo com uma cifra tanto o infinitamente pequeno como o infinitamente grande, o átomo e o cosmos", sendo que agora até "a parte infinitamente pequena perde também (...) o seu caráter indeterminado". " Nesse sentido, podemos de fato interpretar que, na obra jüngeriana, a eliminação do indeterminado anda de mãos dadas com a eliminação da subjetividade individual. Pois, àquele caráter de máscara, corresponde o "rosto de um novo tipo de humanidade em que a pessoa singular (Einzelne) atinge a expressão, não enquanto indivíduo — o cidadão, o Bürger —, mas enquanto tipo", como já comentou Edmundo Cordeiro. "Impressão metálica e cosmética, metallichen e kosmetichen Eindruck, que resulta da observação dos traços da 'construção orgânica', da Gestaltung no homem”. ${ }^{45}$

\footnotetext{
${ }^{42}$ HUYSSEN, Andreas. Fortifying the Heart: Totally Ernst Jünger's Armored Texts, op. cit., p. 6.

${ }^{43}$ JÜNGER, Ernest. O trabalhador. Domínio e figura, op. cit., \$37, p. 137.

${ }^{44}$ Ibidem, $\$ 41$, p. 147.

${ }^{45}$ CORDEIRO, Edmundo. Técnica, mobilização e figura. A técnica segundo Ernst Jünger. Revista de Comunicação e Linguagens, Lisboa, n. 25/26, mar./1999, Ediçôes Cosmos, p. 5. Disponível em: <http://bocc. unisinos.br/pag/cordeiro-edmundo-trab-figura.pdf>.
} 
De forma paradoxal para o pensamento liberal, Jünger aponta que a verdadeira liberdade é aquela de se colocar em sacrifício em prol da mobilização total: a "mais profunda felicidade do homem consiste em ser sacrificado; e a suprema arte do comando, em indicar objetivos que sejam dignos do sacrifício". ${ }^{46} \mathrm{~A}$ isso se liga o realismo heroico que implica a configuração do tipo do trabalhador no mundo da técnica:

o motor não é o dominador, mas o símbolo do nosso tempo, a imagem simbólica de um poder para o qual a explosão e a precisão não são quaisquer opostos. Ele é o instrumento ousado de uma espécie humana que consegue com entusiasmo romper no ar e que vê neste ato ainda uma comprovaçáo da ordem. A partir desta atitude, que não é realizável nem para o idealismo nem para o materialismo, mas que tem de ser referida como um realismo heroico, dá-se aquela medida mais extrema da força de ataque de que estamos precisados. Os seus portadores são da espécie daqueles voluntários que saudaram com júbilo a grande guerra e que saúdam tudo quanto dela se seguiu e seguirá. ${ }^{47}$

Enfim, se Jünger, segundo nossa leitura, propõe uma "solução" (conservadora $e$ revolucionária) para o problema da técnica, como então ler sua obra tendo como referência a tradição intelectual anterior, tendo em vista que (a) em $O$ trabalhador não há referências explícitas a nenhum autor ou obra e (b) de maneira que possamos fazer uma abordagem que possibilite-nos escapar da teia autorreferente do discurso conservador sobre a técnica? Iniciemos brevemente com o segundo ponto, pois será diretamente articulado com o que já viemos discutindo, para em seguida passar ao primeiro.

\section{A mitologização jüngeriana como utopia conservadora}

Segundo Pedro Rocha de Oliveira, seguindo os passos da crítica de Kracauer, há uma "apresentação mitológica da técnica" própria da cultura de massas que, por sua vez, traz a ambiguidade de, por um lado, chamar atençáo para o processo de desencantamento do mundo e, por outro, se volta contra esse mesmo desencantamento mediante sua mitologização. "Nos dois movimentos, é trazido à esfera da aparência o paradoxo fetichista do mito: o fato de que ele é criação do ser humano, mas deve atuar sobre o ser humano desde fora, como garantia objetiva do sentido das coisas, ou como redenção da finitude prosaica". ${ }^{48}$ Acreditamos que esse aspecto, que o autor apresenta a respeito da relação entre técnica, cul-

\footnotetext{
${ }^{46}$ JÜNGER, Ernst. O trabalhador. Domínio e figura, op. cit., \$22, p. 94-95.

${ }^{47}$ Ibidem, $\$ 8$, p. 67.

${ }^{48}$ OLIVEIRA, Pedro Rocha de. Fetichismo e ornamento na teoria da cultura de Siegfried Kracauer. Sintese — Revista de Filosofia, v. 39, n. 124, p. 250-251, 2012. Disponível em: <http://faje.edu.br/periodicos/index. php/Sintese/article/view/1804>.
} 
tura de massas e mitologização, fica mais evidente na obra de Jünger, onde a subsunção do indivíduo na "mobilização total" é o paroxismo da morte da política, desde que se entenda por política, primeiro, a capacidade de mediação num contexto pluralista e, segundo, a capacidade de distanciamento e reflexão. ${ }^{49}$

Chamamos atenção, como faz o autor, para o papel que cumpre a estetização da técnica nesse aspecto ilusório de um domínio da técnica pela vontade: "O poder que a disposição estética exerce sobre a técnica para exibi-la é portanto um falso poder, pois obscurece o fato de que, na vida prática, a técnica não é controlada e determinada, mas ela mesma controla e determina a vida" 50

Esse juízo sobre a técnica, é importante termos em conta, podemos relacioná-lo a um certo horizonte intelectual que era compartilhado por autores tais como Georg Simmel, que teve influência direta sobre (chegou a ser professor de) Kracauer e Walter Benjamin. Em "O dinheiro na cultura moderna" (1896) e em "A divisão do trabalho como causa da diferenciação da cultura subjetiva e objetiva" (1900), Simmel afirmava que a época moderna "conseguiu separar e autonomizar o sujeito e o objeto", por um lado "para que ambos realizassem o próprio desenvolvimento de forma mais pura e mais rica"; e, no sentido da via de mão dupla (cultivo) entre sujeito e cultura objetivada, "em cada realização temos sobre nós uma norma, um padrão de referência, uma totalidade ideal pré-formada que, justamente por meio desta realização, é transportada para a forma da realidade". ${ }^{1}$ Por outro lado, já apontava Simmel, a autonomização da esfera objetivada da técnica moderna provocaria uma rachadura na dimensão do cultivo (ligada à Bildung, formação) na medida em que o mundo objetivado impóe-se, cada vez mais, em sua incomensurabilidade e nas suas próprias leis. "Na técnica, nas organizaçóes de cada tipo, nas empresas e nas profissóes impóe-se cada vez

${ }^{49}$ Para uma reflexão sobre a atualidade das questôes relativas ao domínio da técnica, a partir de uma leitura crítica de Heidegger, cf. MAURER, Reinhart. O que existe de propriamente escandaloso na filosofia da técnica de Heidegger, op. cit. Agradeço a Sérgio Ricardo da Mata pela indicação do artigo, que mostra muito bem a atualidade desse debate a respeito do pensar sobre a técnica, para além da questão da simpatia ou não com relação a figuras como Jünger e especialmente Heidegger. "Pode-se suspeitar aqui, em Jünger — quanto ao mais, aliás, um conservador - , de uma fuga para frente, em face das destrutivas possibilidades e efetividades da técnica moderna, principalmente da técnica bélica, que o soldado Jünger vivenciara na pele. As asserçóes de Heidegger, segundo as quais seria necessário corresponder à essência da técnica, parecem ter raízes semelhantes. Todavia, também em Bloch e Marx deparamos com as mesmas esperanças numa futura harmonia entre o homem e a técnica; e o american way of life vai nessa mesma direção, sem teorizar muito a respeito. Na teoria, esse é um complexo inusitado, 'de esquerda' como 'de direita'. Der Arbeiter, de Jünger, é uma espécie de proletariado titânico, mitologizado, no papel de liderança histórico-universal, que lhe foi atribuído por Marx" (ibidem, p. 417). Não seria, também, o nosso recente reviver de um ufanismo desenvolvimentista, à parte a dimensão das políticas sociais, uma atualização de uma política irrefletida baseada num mito do "crescimento econômico" (que ignora aspectos ambientais e mesmo socioeconômicos, no sentido da divisão de classes quanto à carga tributária, por exemplo)?

${ }^{50}$ OLIVEIRA, Pedro Rocha de. Fetichismo e ornamento na teoria da cultura de Siegfried Kracauer, op. cit., p. 246.

${ }^{11}$ Cf. SOUZA, Jessé; ÖELZE, Berthold (Org.). Simmel e a modernidade. Tradução Jessé Souza, Berthold Öelze, Sebastiāo Rios e Clarissa Rios. Brasília: Ed. Universidade de Brasília, 1998, respectivamente p. 23 e 47. 
mais o domínio das próprias leis das coisas, que separam tudo isso das nuances de personalidades singulares - como, tendencialmente, a nossa imagem da natureza perde mais e mais os traços humanos em favor de uma legislação objetiva. ${ }^{52}$

A esse problema da autonomização do mundo da técnica, portanto, se somava agora o da estetização da mesma, em benefício de uma mitologia política reacionária. Em sua crítica à coletânea Guerra e guerreiros, editada por Jünger, Benjamin dizia que "apesar de todas as suas frases sobre elementos eternos e originários", os autores fracassavam em sua mensagem devido a sua "pressa tão pouco aristocrática, inteiramente jornalística, com que tentam apropriar-se da atualidade sem terem compreendido o passado". ${ }^{33} \mathrm{De}$ fato, em $O \mathrm{tra}$ balhador, ao mesmo tempo que Jünger fala da nova arte elaborada através dos novos meios técnicos - cinema, rádio e fotografia - e em que se dá, a seu ver, uma desindividualização, ele expressa o desejo por um novo tipo de arte ligada ao mito: "Do mesmo modo que o vencedor escreve a história, isto é, cria o seu mito", diz Jünger, "ele determina aquilo que deve valer como arte". ${ }^{4}$

Pelo que foi até aqui exposto, enfatizemos: na obra de Jünger há três pontos articulados: (i) o elogio da totalidade da técnica sem nostalgia romântica, (ii) a junção do elemento cultual e vitalista com a técnica e (iii) o descarte da subjetividade. Daqui, o passo mais arriscado é interpretar as mençóes que Jünger faz ao romantismo, já que em $O$ trabalhador não há referências explícitas a nomes e obras. Vejamos uma possível referência indireta de Jünger ao primeiro romantismo alemão. Segundo ele, tendo em vista a nova totalidade em expansão,

O espaço vital ganha em inequivocidade, em evidência; ao mesmo tempo, cresce a ingenuidade, a inocência com que se movimenta neste espaço. Mas aqui esconde-se a chave para um outro mundo.

Levanta-se agora a questão de saber se atrás das máscaras do tempo nada mais há para procurar senáo a morte do indivíduo que enrijece a fisionomia e que, no fundo, significa mais e algo mais doloroso do que apenas o corte que separa dois séculos. Pois este corte significa, ao mesmo tempo, a última volatilização da alma antiga, cuja dissolução começou já cedo, com a conclusão de estados universais e antes da emergência da pessoa absoluta. ${ }^{55}$

Temos, então, o tipo enquanto "pessoa absoluta" [absolute Person], que emerge numa totalidade em que se dissolve qualquer individualidade e/ou particularismo de classe. Mas trata-se mais do que isso. Segundo Jünger, a figura, que "póe ao seu serviço o sentido do

\footnotetext{
${ }^{52}$ Ibidem, p. 23, grifo nosso.

${ }^{53}$ BENJAMIN, Walter. Magia e técnica, arte e política: ensaios sobre literatura e história da cultura. Tradução Sérgio Paulo Rouanet; prefácio Jeanne Marie Gagnebin. 7. ed. São Paulo: Brasiliense, 1994, p. 64. (Obras escolhidas v. 1)

${ }^{54}$ JÜNGER, Ernst. O trabalhador. Domínio e figura, op. cit., $\$ 61$, p. 198.

${ }^{55}$ Ibidem, $\$ 39$, p. 142-143.
} 
tipo, ou seja, do trabalhador", não "se pode captar através do conceito universal e espiritual de infinitude, mas através do conceito particular e orgânico de totalidade". ${ }^{56}$ Além disso, temos a "inocência" e a "ingenuidade" que se mostram às portas de "um outro mundo". Já que, como observamos, as referências a outros autores são inexistentes em todo o longo ensaio, talvez possamos remeter a ingenuidade aqui à Poesia ingênua e sentimental (1796), de Friedrich Schiller, onde há a tematização do eu subjetivo diante do problema do recuo da natureza enquanto horizonte harmônico.

Em seu Poesia ingênua e sentimental, Schiller diferenciava dois estados ou atitudes do homem frente à natureza: primeiro, (i) o campo do ingênuo, "o da simplicidade natural, onde o homem ainda atua simultaneamente com todas as suas forças como uma unidade harmônica, onde, por conseguinte, o todo de sua natureza se exprime plenamente na realidade" e nesse caso, "o que tem de constituir o poeta é a imitação mais completa possível do real"; segundo, (ii) o campo do sentimental, correspondente ao estado da cultura, onde, ao contrário, "o atuar em conjunto harmônico de toda a natureza é apenas uma Ideia", e "o que tem de constituir o poeta é a elevação da realidade ao Ideal". Aqui já se dá, podemos dizer, a reflexão sobre a própria atividade poética. Sendo, portanto, os dois estados extremamente diferentes, há no entanto, diz Schiller, "um conceito mais alto" que os abarca,

e não é de se estranhar que esse conceito coincida com a ideia de humanidade. (...) Esse caminho que os poetas modernos seguem é o mesmo que (...) o homem em geral tem de trilhar, tanto individualmente quanto no todo. A natureza o faz uno consigo, a arte o cinde e desune; pelo Ideal, ele retorna à unidade..$^{57}$

Como aponta Philippe Lacoue-Labarthe, "Schiller acrescenta logo que o ideal sendo infinito e, como tal, inacessível, o ser da cultura 'não pode nunca vir a ser perfeito em sua espécie". 58 Sendo o ideal infinito, diz o autor, trata-se de um "acabamento assintótico", isto é, nunca pode atingir seu fechamento ou conclusão absolutos. Simmel, um século depois, ainda dirá que a cultivação é "uma tarefa situada no infinito". 59

Assim, destaquemos: tal ideal de uma harmonia natural é ao mesmo tempo assintótico justamente pelo fato de que tal harmonia preestabelecida já não é mais passivel de ser ontologicamente sustentada. A natureza passara a ser mero material para a atividade técnica. $\mathrm{E}$ a nosso ver, tal ideal assintótico coloca-se diretamente em relação ao problema da totalida-

\footnotetext{
${ }^{56}$ Ibidem $\$ 41$, p. 147 , grifo nosso.

${ }^{57}$ Schiller, Friedrich. Poesia ingênua e sentimental. Tradução Marcio Suzuki. São Paulo: Iluminuras, 1991, p. 61 apud LACOUE-LABARTHE, Philippe. A imitação dos modernos: ensaios sobre arte e filosofia. Organização Virginia de Araujo Figueiredo e João Camilo Penna; tradução João Camilo Penna et al. São Paulo: Paz e Terra, 2000, p. 215.

${ }^{58}$ LACOUE-LABARTHE, Philippe. A imitação dos modernos, op. cit., 2000, p. 215.

${ }^{59}$ Cf. SOUZA, Jessé; ÖELZE, Berthold (Org.). Simmel e a modernidade, op. cit., p. 95.
} 
de, ou totalização. Recordemos que a distinção entre razão e natureza foi a base para que Kant se ativesse na particularidade do homem como animal carente que, pelo domínio da razão, pôde desenvolver sua história, história essa independente, pois, dos ciclos da natureza (e dizemos isso tanto do ponto de vista do domínio técnico sobre os meios de subsistência como da própria temporalidade). ${ }^{60}$ Mas, no que diz respeito à reflexão sobre o poético, essa distinção entre mundo humano e natureza corresponde a uma problematização que levará à reflexão sobre a tragédia, ou mais precisamente, sobre o sentido trágico dos tempos modernos.

Concomitantemente ao impacto das críticas kantianas, o poeta Hölderlin levava a cabo um trabalho de "traduçáo" do legado grego que era uma forma também de caracterizar a modernidade ocidental, e o legado de Hölderlin será reivindicado mais de um século depois. No contexto da tardia unificação nacional, os alemães fizeram sua leitura própria do legado grego, em que produziram uma virada de foco do classicismo para o - usando o termo nietzschiano - dionisíaco. O próprio Hölderlin teria presença marcante na obra heideggeriana na década de 1930. No cerne do trabalho de "tradução" levado a cabo por Hölderlin, o Moderno - ou o Hespérico ou Ocidental — seria o inverso do Antigo, do Oriental. O que nos seria próprio são a sobriedade e a clareza de exposição, pois nosso reino é o da finitude, ao contrário do aórgico (i.e., não feito pelo homem) grego em que o domínio sobre a natureza pelo homem não era sequer concebido e o sentido trágico era o da derrota do herói frente às forças da natureza, cabendo à arte a simbolização — "sóbria" — da vida. O Moderno é também a esfera da morte lenta, "se pensarmos no que deve ser necessariamente um trágico moderno ('Pois, para nós, o trágico consiste no fato de nos afastarmos do reino dos vivos lentamente (...) e não de sermos devorados pelas chamas que não soubemos amestrar')", coloca Lacoue-Labarthe, citando o poeta; "ou então da 'errância sob o impensável', no estilo do Édipo em Colônia ou do fim de Antígona: o abandono e a loucura, não a morte bruta, física; o espírito atingido, não o corpo". ${ }^{61}$

Como havia colocado o autor, "uma certa interpretação da tragédia, ao explicitar-se como filosófica e, sobretudo, ao querer-se como tal, é a origem ou a matriz do que se convencionou chamar, no período pós-kantiano, de pensamento especulativo", ou seja, "o pensamento dialético ou, retomando a terminologia heideggeriana, a onto-teologia consumada". ${ }^{2}$ Tal pensamento especulativo sofre uma cesura com Hölderlin, pois a "hiperbológica" fundamenta o esquema do "duplo retorno" no último pensamento de Hölderlin segundo o qual o excesso do especulativo se transforma no excesso da submissão à finitude: "a lição, no que diz respeito à própria tragédia", diz o autor, "é das mais claras:

${ }^{60}$ Cf. KANT, Immanuel. Ideia de uma história universal de um ponto de vista cosmopolita. Organização Ricardo R. Terra, traduçáo Rodrigo Naves e Ricardo R. Terra. 3. ed. São Paulo: Editora WMF Martins Fontes, 2011, p. 1-22.

${ }^{61}$ LACOUE-LABARTHE, Philippe. A imitaçâo dos modernos, op. cit., 2000, p. 221-222.

${ }^{62}$ Ibidem, p. 181. 
quanto mais o trágico se identifica com o desejo especulativo do infinito e do divino, mais a tragédia o expóe como a rejeição na separação, na diferenciação, na finitude. A tragédia é, em suma, a catarse do especulativo". ${ }^{63}$

A arte grega, portanto, "é inimitável porque é uma arte e porque a sobriedade que ela nos indica é, ou deve ser em nós, natureza", ${ }^{64}$ aponta Lacoue-Labarthe. No entanto, com "mais violência que [Friedrich] Schlegel, a Grécia inventada por Hölderlin é no fundo aquela que não cessará de assombrar o imaginário alemão até hoje, e que atravessará em todo caso o conjunto do texto filosófico de Hegel a Heidegger, passando por Nietzsche". ${ }^{5}$

Em Sobre a dor, de 1934, Jünger menciona Hölderlin para lamentar que a juventude "se vê arrancada de seu 'ardente elemento". ${ }^{66}$ Mas nos detenhamos um pouco ainda no âmbito do primeiro romantismo e do idealismo alemão, pois com Schelling póe-se a problematização da subjetividade frente à esfera do ideal absoluto. $\mathrm{O}$ ponto de chegada ainda será o tema do acabamento assintótico, em que a tragédia, como artifício estético e filosófico, abre-se para o sublime (kantiano) e deste para a história.

Schelling participou de um embate no seminário luterano de Tübingen tendo como centro as ideias de Kant que, ao entrarem de forma clandestina no instituto, seriam apropriadas pelos teólogos no sentido de reforçar o dogma da teoria da salvaçáo divina. Quer dizer, a distinção que Kant fazia entre mundo fenomênico, passível de conhecimento, e suprassensível, seria lida pelos teólogos do instituto no sentido do reforço da fé, assim como a autoridade da religiâo. (Recordando, a Crítica da Razão Prática postulava a liberdade da razão, que por outro lado se submetia ao imperativo moral. O dogmatismo se aproveitava da distinção entre fenomênico e suprassensível, mantida nas críticas kantianas, para reafirmar o horizonte moral como o dogma religioso.) Nesse contexto, no qual também teria influência a obra de Espinosa e a filosofia de Fichte, Schelling julgará que o criticismo tinha poucas armas contra o dogmatismo ao fundar seu sistema inteiro apenas na faculdade de conhecer, e não no nosso ser originário. Assim,

Como escreve Fichte na Doutrina-da-ciência, seria preciso tornar evidente que: "o eu póe a si mesmo e é, em virtude desse mero pôr-se por si mesmo; e vice-versa: o eu é e, em virtude de seu mero ser, póe seu ser”. Se, assim, o eu póe a si mesmo e somente é em virtude desse seu pôr-se, então ele é absoluto, pois, como diria ainda Schelling, "o absoluto somente pode ser dado por meio do absoluto". ${ }^{67}$

\footnotetext{
${ }^{63}$ Ibidem, p. 205, grifo nosso.

${ }^{64}$ Ibidem, p. 222.

${ }^{65}$ Ibidem, p. 219.

${ }^{66}$ JÜNGER, Ernst. Sobre el dolor. In: JÜNGER, Ernst. Sobre el dolor, op. cit., 2003, p. 32.

${ }^{67}$ VACCARI, Ulisses R. A crítica do jovem Schelling à teologia de Tübingen no contexto da querela do panteísmo. Cadernos Espinosanos (USP), v. XXXIV, p. 184, 2011.
} 
Temos, pois, um eu que póe a si mesmo, sendo absoluto. Mas, dizendo assim, como proceder a uma distinção com relação à teologia, mais ainda, contra o dogmatismo que se apropriara à sua maneira dos postulados da razão prática kantiana? Schelling desenvolve o argumento de que a relação entre o particular e o absoluto, entre homem e Deus não se dá da mesma forma que a relação entre sujeito e objeto, e fundamenta tal argumento recorrendo ao conceito de intuiçâo intelectual, no sentindo de Amor Dei intellectualis que lhe dá Espinosa em sua Ética. Trata-se de uma intuição intelectual do eu por si mesmo, independente da mediaçáo do sensível e onde inexiste "toda e qualquer relação entre sujeito e objeto" e por isso "sua ação se torna uma ação absoluta e é por meio dela, nesse momento 'em que desaparecem para nós tempo e duraçáo', que se realiza aquela passagem procurada do finito ao infinito, da filosofia teórica para a filosofia prática". ${ }^{68}$

Assim, Schelling "tem em vista mostrar que o Absoluto não é um objeto fora do eu, mas, antes, um momento do próprio eu, em sua intuição de si mesmo, e que antecede ou sucede a sua autoconsciência". ${ }^{69}$ E esse movimento do finito ao infinito deve também transmutar-se do infinito ao finito, no sentido da fundamentação da filosofia. Nas palavras de Ulisses R. Vaccari, cuja exposição seguimos, Schelling "tem em vista mostrar que o Absoluto não é um objeto fora do eu, mas, antes, um momento do próprio eu, em sua intuiçáo de si mesmo, e que antecede ou sucede a sua autoconsciência". ${ }^{70}$ Deus deixa de ser um Deus pessoal para se tornar o Ser Absoluto, com o qual se liga o sujeito pela intuiçáo intelectual, pela qual o sujeito torna-se também um eu absoluto. Essa equivalência entre Deus e o eu absoluto deve ser considerada "apenas um ideal prático, inalcançável ou alcançável apenas por uma aproximação prática infinita”. ${ }^{71}$

Como coloca Jean-François Courtine, a oposição de Schelling ao "falso criticismo dos teólogos de Tübingen" era também uma oposição ao que tal apropriação das ideias kantianas implicava em termos de "aproximação e a união dos termos opostos". O que quer dizer: tratava-se de se opor à noção de um Deus moral "encarregado, em última instância, de eliminar todo conflito, todo combate entre o Eu e o mundo", com sua promessa de "uma derradeira reconciliação entre as exigências do Eu, as injunçôes nele da lei e a ordem do mundo" ${ }^{72} \mathrm{O}$ autor destaca, a partir daí, a importância que terá para Schelling, no plano estético, a tragédia.

Em primeiro lugar, Schelling afasta-se da noção romântica de se lançar "nos braços do infinito" ou de se perder no "mundo juvenil" (frases que Courtine retira de Hölderlin),

\footnotetext{
${ }^{68}$ Ibidem, 185.

${ }^{69}$ Ibidem, 186.

${ }^{70}$ Idem.

${ }^{71}$ Ibidem, 188.

${ }^{72}$ COURTINE, Jean-François. Tragédia e sublimidade. A interpretação especulativa do Édipo Rei no limiar do idealismo alemão. In: COURTINE, Jean-François. A tragédia e o tempo da história. Tradução Heloisa B. S. Rocha. São Paulo: Ed. 34, 2006, p. 182.
} 
opondo-se assim à diluição de toda a consistência do mundo objetivo, pois tal diluição faria perder "seu estatuto essencial de Widerstand (resistência)". ${ }^{73}$ Assim, a tragédia, como proposta estética, parte de dois pontos: por um lado, (i) deve-se ter com conta que a época trágica correspondia a um conflito frontal entre a livre afirmação do Eu (Selbstmacht) e uma potência definida por seu excesso ou sua sobremedida (Übermass), e tal tragicidade há muito se dissipara diante da luz da razão $;^{74}$ mas, por outro lado, (ii) a tragédia poderia servir, na modernidade, como tentativa de conciliação dos dois imperativos diametralmente opostos, o do dogmatismo - o "Anula-se a ti mesmo!" diante da causalidade absoluta — e o do criticismo - "Sê!". ${ }^{5}$

Sem entrarmos em muitos pormenores, cabe destacar como Schelling procede a uma leitura particular do sublime: assim como Schiller, procura ir além de Kant que, para o sublime, utiliza (na Terceira Crítica) exemplos tirados da natureza, para pensar também o que o aproxima ou distingue do sublime da história. Para Schelling, o estudo do sublime, em oposição ao da beleza, não marca "nenhum retorno ao sujeito, à subjetividade do sujeito que julga esteticamente", e isso "mesmo quando a análise se dirige expressamente ao efeito produzido sobre o espectador". ${ }^{76}$ Mas, sendo os limites de toda apresentação trágica os limites da própria arte, o espetáculo da tragédia é uma ilusão que antecipa a reunificação absoluta, mas assintótica, dos termos antagônicos, "como quer que se queira chamá-los: liberdade-necessidade, finito-infinito, Eu-objeto absoluto" ${ }^{77}$

No final do século XVIII, o acabamento assintótico, excluindo Hegel e sua dialética teleológica, é bastante comum, está presente nas Conferências sobre o destino do sábio (1794), de Fichte, no fragmento 116 de Schlegel do Athenaeum (1798-1800) sobre a poesia progressiva (ou seja, sobre a poesia romântica) e também no Sistema do idealismo transcendental (1800), de Schelling. Contudo, aponta o autor, "infinitização quer também dizer absolutização" e Schiller acaba por esboçar "potencialmente o processo da lógica dialética". ${ }^{78}$

O recuo da natureza como fundamento ontológico foi acelerado no final do século XIX devido às rápidas mudanças decorrentes do processo de industrializaçáo e urbanização, constituindo o horizonte histórico do surgimento dos movimentos neorromânticos e reacionários. Na segunda metade da década de 1910, a expansão industrial e urbana se conjugaria com a Primeira Guerra Mundial em que pela primeira vez as cidades e os civis seriam alvo sistemático dos ataques bélicos e onde a morte viria em massa. Esse cenário de destruição, para o qual Benjamin elaborou a alegoria do Anjo da História, acabava por realimentar a expansão industrial e urbana.

\footnotetext{
${ }^{73}$ Ibidem, p. 184-186.

${ }^{74}$ Ibidem, p. 187.

${ }^{75}$ Ibidem, p. 194.

${ }^{76}$ Ibidem, p. 199.

${ }^{77}$ Ibidem, p. 191.

${ }^{78}$ LACOUE-LABARTHE, Philippe. A imitação dos modernos, op. cit., 2000, p. 215.
} 
Conforme o próprio Jünger comenta em suas narrativas da Primeira Guerra, o tradicional combate homem a homem dava lugar às tempestades de aço que por vezes destroçava os corpos dos soldados antes mesmo que pudessem ver o rosto de seus inimigos. Essa experiência da guerra, na obra de Jünger, talvez possa ser vista como o índice de um sentido de tragédia que implica o abandono do caráter assintótico. Para Jünger,

a batalha é para o guerreiro um acontecimento que se cumpre numa ordem superior; o conflito trágico é para o poeta um estado no qual o sentido da vida pode ser captado de um modo particularmente claro; e uma cidade em chamas ou desertificada por um tremor de terra é para o criminoso um campo de atividade acrescida.

Do mesmo modo, o homem crente participa num círculo mais alargado da vida com sentido. O destino, através da infelicidade e do perigo, assim como através do milagre, inclui-o imediatamente numa ordem regente mais poderosa, e o sentido desta intervenção é reconhecido na tragédia. ${ }^{79}$

Em vez de uma totalidade ideal, no sentido de Simmel, como mediação entre sujeito e cultura objetivada e condizente com a noção do acabamento assintótico, temos a totalidade do trabalho sem sujeito racional-reflexivo e sem mediaçáo. Impóe-se o sacrifício guerreiro através da figura que "póe ao seu serviço o sentido do tipo, ou seja, do trabalhador", que não "se pode captar através do conceito universal e espiritual de infinitude, mas através do conceito particular e orgânico de totalidade". ${ }^{80}$

\section{Considerações finais}

Pelo que foi anteriormente exposto, podemos pensar num tipo de contraposição inerente aos tempos modernos que se radicaliza após as revoluçóes burguesas: aquela entre (i) o reconhecimento e/ou aceitação do caráter inerentemente aberto de um contexto a partir do qual se reivindicará a unidade a que se chamará de História e (ii) as mitologias políticas que, apelando a noçóes ligadas a alguma forma de "eterno retorno" — ou afirmaçóes subjacentes à noção de "retorno do recalcado" —, afirmam o caráter absoluto e atemporal de suas verdades, em que é prescindível toda legitimação racional. ${ }^{81}$ Assim, sem mediação ou reflexão, seja sobre seus conceitos, seja sobre sua historicidade, o caráter de problema da técnica é eliminado em favor do elogio do que Jünger chama de "máscara" do novo domínio que se dá através

\footnotetext{
${ }^{79}$ JÜNGER, Ernst. O trabalhador. Domínio e figura, op. cit., \$13, p. 77.

${ }^{80}$ Ibidem $\$ 41$, p. 147.

${ }^{81}$ Cf. BLUMENBERG, Hans. El mito y el concepto de realidad. Tradução Carlota Rubies. Barcelona: Herder, 2004.
} 
da uniformização. ${ }^{82}$ Como apontava Benjamin, uma estetização a serviço de uma mitologia política, cujo sentido, podemos dizer, é o de uma utopia conservadora.

Nesse sentido, cabe também investigar como a Gestalt jüngeriana — e sua apologia da "segunda consciência, mais fria", que nos dá a capacidade de vermo-nos "como um objeto" — ${ }^{83}$ teria relação com o horizonte da problemática sobre a estética, mais precisamente da estética enquanto posição do sujeito na tensão entre corpo/sentidos e a razão. ${ }^{84}$ Tensão essa que é recolocada no contexto em que emergem os dilemas sobre fragmentação e totalidade que marcam a era da técnica e a experiência do fascismo. ${ }^{85}$

\section{Referências bibliográficas}

BENJAMIN, Walter. Magia e técnica, arte e politica: ensaios sobre literatura e história da cultura. Tradução Sérgio Paulo Rouanet; prefácio Jeanne Marie Gagnebin. 7. ed. São Paulo: Brasiliense, 1994. (Obras escolhidas v. 1)

BLUMENBERG, Hans. El mito y el concepto de realidad. Tradução Carlota Rubies. Barcelona: Herder, 2004.

BLUMENBERG, Hans. "Imitação da natureza": contribuição à pré-história da ideia do homem criador. In: COSTA LIMA, Luiz (Org.). Mimesis e a reflexão contemporânea. Tradução Luiz Costa Lima; revisão técnica Carlinda Nuñez. Rio de Janeiro: EdUerj, 2010. BUCK-MORSS, Susan. Estética e anestética: uma reconsideração de $A$ obra de arte de Walter Benjamin. In: BENJAMIN, Walter et al. Benjamin e a obra de arte: técnica, imagem, percepção. Tradução Marijane Lisboa e Vera Ribeiro; organização Tadeu Capistrano. Rio de Janeiro: Contraponto, 2012.

COELHO, Victor de O. P. A totalidade enquanto problema histórico e categoria teórica: uma abordagem a partir das obras de Humboldt, Simmel e Ernst Jünger. Revista de Teoria da História, ano 4, n. 8, p. 78-105, dez./2012.

. Carl Schmitt, Ernst Jünger e o problema da totalidade na era da técnica. In: BUENO, Roberto (Org.). Carl Schmitt hoje: política, direito e teologia. Sáo Paulo: Max Limonad, 2015, p. 579-601.

\footnotetext{
${ }^{82}$ Cf. JÜNGER, Ernst. O trabalhador. Domínio e figura, op. cit., $\$ 36$.

${ }^{83}$ JÜNGER, Ernst. Sobre el dolor, op. cit., 2003, p. 70.

${ }^{84}$ Cf. CRARY, Jonathan. Técnicas do observador: visão e modernidade no século XIX. Tradução Verrah Chamma, organização Tadeu Capistrano. Rio de Janeiro: Contraponto, 2010.

${ }^{85}$ Cf. BUCK-MORSS, Susan. Estética e anestética: uma reconsideraçáo de $A$ obra de arte de Walter Benjamin. In: BENJAMIN, Walter et al. Benjamin e a obra de arte: técnica, imagem, percepção. Tradução Marijane Lisboa e Vera Ribeiro; organização Tadeu Capistrano. Rio de Janeiro: Contraponto, 2012.
} 
. Entre o niilismo e a legitimidade do espaço simbólico. Diálogo com Schmitt, Heidegger e Blumenberg. Horizonte: Revista de Estudos de Teologia e Ciências da Religião, v. 12, p. 183-210, 2014.

. Ernst Jünger: o sublime da guerra e o tempo como mudança de plano. Dimensóes, v. 30, p. 173-212, 2013.

CORDEIRO, Edmundo. Técnica, mobilização e figura. A técnica segundo Ernst Jünger. Revista de Comunicação e Linguagens, Lisboa, n. 25/26, mar./1999, Ediçóes Cosmos, p. 5. Disponível em: <http://bocc.unisinos.br/pag/cordeiro-edmundo-trab-figura.pdf>. COURTINE, Jean-François. Tragédia e sublimidade. A interpretação especulativa do Édipo Rei no limiar do idealismo alemão. In: COURTINE, Jean-François. A tragédia e o tempo da história. Tradução Heloisa B. S. Rocha. São Paulo: Ed. 34, 2006, p. 182.

CRARY, Jonathan. Técnicas do observador: visão e modernidade no século XIX. Tradução Verrah Chamma; organização Tadeu Capistrano. Rio de Janeiro: Contraponto, 2010.

HANSEN, Miriam. (Prefácio) Perspectivas descentradas. In: KRACAUER, Siegfried. O ornamento da massa: ensaios. Tradução Carlos Eduardo Jordão Machado e Marlene Holzhausen. São Paulo: Cosac Naify, 2009.

HEIDEGGER, Martin. O niilismo europeu. In: HEIDEGGER, Martin. Nietzsche II. Tradução Marco Antônio Casanova. Rio de Janeiro: Forense Universitária, 2007, p. 107-108. HERF, Jeffrey. O modernismo reacionário: tecnologia, cultura e política na República de Weimar e no Terceiro Reich. Tradução Claudio Frederico da S. Ramos. São Paulo: Ensaio; Campinas: Unicamp, 1993, p. 85.

HUYSSEN, Andreas. Fortifying the Heart: Totally Ernst Jünger's Armored Texts. New German Critique, n. 59, Special Issue on Ernst Junger, p. 3-23, Spring/Summer 1993. Disponível em: <http://www.jstor.org/stable/488219>. Acesso em: 2 maio 2011.

JÜNGER, Ernst. A mobilização total. Tradução e notas de Vicente Sampaio. Natureza Humana, v. 4, n. 1, p. 189-216, jan./jun. 2002. Disponível em: <http://pepsic.bvsalud.org/ scielo.php?script $=$ sci_arttext\&pid $=$ S1517-24302002000100006>.

. A guerra como experiência interior. Tradução Armando Costa e Silva; revisão a partir do alemão: Roberto de Moraes. Lisboa: Ulisseia, 2005.

. O coração aventuroso. Traduçáo Ana Cristina Pontes. Lisboa: Cotovia, 1991.

On Danger. New German Critique, n. 59, Special Issue on Ernst Junger, p. 27-32, Spring/Summer 1993. Disponível em: <http://www.jstor.org/stable/488221> . Acesso em: 24 maio 2011.

. O trabalhador. Domínio e Figura. Introdução, tradução e notas: Alexandre Franco de Sá; prefácio Nuno Rogeiro. Lisboa: Hugin, 2000, \$12, p. 94. (Para consulta ao original: Der Arbeiter. Herrschaft und Gestalt. $3^{\text {te }}$ Auflage. Stuttgart: Klett-Cotta, 2007). 
- Sobre el dolor. In: Sobre el dolor, seguido de La mobilización total y Fuego y movimiento. Tradução do alemão Andrés Sánchez Pascual. 2. ed. Barcelona: Tusquets, 2003. . Tempestades de aço. Tradução e notas Marcelo Backes. 1. edição eletrônica. Sáo Paulo: Cosac Naify, 2013.

. War and Photography. Tradução Anthony Nassar. New German Critique, n. 59, Special Issue on Ernst Junger, p. 24-26, Spring/Summer 1993. Disponível em: <http:// www.jstor.org/stable/488220>. Acesso em: 24 maio 2011.

KAES, Anton. The Cold Gaze: Notes on Mobilization and Modernity. New German Critique, n. 59, Special Issue on Ernst Junger, p. 105-117, Spring/Summer. Disponível em: <http://www.jstor.org/stable/488225>. Acesso em: 2 maio 2011.

KANT, Immanuel. Ideia de uma história universal de um ponto de vista cosmopolita. Organização Ricardo R. Terra; tradução Rodrigo Naves e Ricardo R. Terra. 3. ed. São Paulo: Editora WMF Martins Fontes, 2011.

KRACAUER, Siegfried. O ornamento da massa. In: KRACAUER, Siegfried. O ornamento da massa: ensaios. Tradução Carlos Eduardo Jordão Machado e Marlene Holzhausen. São Paulo: Cosac Naify, 2009.

. De Caligari a Hitler: una historia psicológica del cine alemán. Tradução Héctor Grossi. Barcelona/Buenos Aires/México: Paidós, 1985.

LACOUE-LABARTHE, Philippe. A imitação dos modernos: ensaios sobre arte e filosofia. Organização Virginia de Araujo Figueiredo e João Camilo Penna; traduçáo João Camilo Penna et al. Sáo Paulo: Paz e Terra, 2000.

LEVIN, Thomas Y. Introduction. In: KRACAUER, Siegfried. The mass ornament: Weimar Essays. Tradução, edição e introdução Thomas Y. Levin. Cambridge/Massachusetts/London/ England: Harvard University Press, 1995, p. 1-30.

MAURER, Reinhart. O que existe de propriamente escandaloso na filosofia da técnica de Heidegger. Natureza Humana, v. 2, n. 2, p. 403-427, 2000, p. 404-405.

MARTINS, Hermínio. Tecnologia, modernidade e política. Lua Nova, n. 40, p. 282-320, 1997.

NIETZSCHE, Friedrich. A vontade de poder. Tradução e notas Marcos Sinésio Pereira Fernandes, Francisco José Dias de Moraes; apresentaçáo Gilvan Fogel. Rio de Janeiro: Contraponto, 2008.

OLIVEIRA, Pedro Rocha de. Fetichismo e ornamento na teoria da cultura de Siegfried Kracauer. Sintese - Revista de Filosofia, v. 39, n. 124, p. 250-251, 2012. Disponível em: $<$ http://faje.edu.br/periodicos/index.php/Sintese/article/view/1804>.

SOUZA, Jessé; ÖELZE, Berthold (Org.). Simmel e a modernidade. Tradução Jessé Souza, Berthold Öelze, Sebastião Rios e Clarissa Rios. Brasília: Ed. Universidade de Brasília, 1998. 
SPENGLER, Oswald. O homem e a técnica. Tradução João Botelho; prefácio Luís Furtado. 2. ed. Lisboa: Guimarães Editores, 1993.

VACCARI, Ulisses R. A crítica do jovem Schelling à teologia de Tübingen no contexto da querela do panteísmo. Cadernos Espinosanos (USP), v. XXXIV, p. 167-193, 2011. 